\title{
GAMBARAN KEBIASAAN SARAPAN DAN STATUS GIZI MAHASISWA GIZI DAN NON-GIZI UNIVERSITAS MUHAMMADIYAH SURAKARTA
}

\author{
DESCRIPTION OF BREAKFAST BEHAVIOUR AND NUTRITIONAL STATUS OF NUTRITION AND \\ NON-NUTRTITON STUDENTS AT UNIVERSITAS MUHAMMADIYAH SURAKARTA
}

\author{
Dyah Intan Puspitasari ${ }^{1}$, Ayik Rahmani ${ }^{2}$ \\ ${ }^{1-2}$ Prodi Ilmu Gizi, Fakultas Ilmu Kesehatan, Universitas Muhammadiyah Surakarta \\ Email Korespondensi : Dyah.Puspitasari@ums.ac.id
}

\begin{abstract}
Abstrak
Mahasiswa gizi yang mendapatkan perkuliahan tentang ilmu gizi dan kesehatan dianggap memiliki pengetahuan yang lebih dibandingkan mahasiswa non-gizi. Pengetahuan yang dimiliki mahasiswa gizi akan membentuk perilaku hidup sehat seperti kebiasaan sarapan sehat dan teratur untuk terbentuknya status gizi yang optimal. Penelitian ini bertujuan untuk melihat gambaran kebiasaan sarapan dan status gizi antara mahaiswa gizi dan non-gizi. Metode penelitian ini adalan penelitian observasional dengan desain cross sectional. Sampel penelitian dipilih secara purposive sampling sejumlah 39 mahasiwa gizi dan 39 mahasiswa non-gizi. Data jenis dan frekuensi sarapan diambil dengan metode food record selama 7 hari berturut-turut dan data status gizi (IMT/U) diambil dengan pengukuran berat badan dan tinggi badan. Hasil penelitian menunjukkan bahwa mahasiswa gizi $(91,2 \%)$ dan non gizi $(79,4 \%)$ kebanyakan mengonsumsi sarapan dengan jenis snack $(<15 \%$ AKG), sarapan dengan frekuensi tidak teratur (79,4\% untuk mahasiswa gizi dan 100\% untuk mahasiswa non-gizi), serta memiliki status gizi baik (70,6\% untuk mahasiswa gizi dan 61,8\% untuk mahasiswa non-gizi. Mahasiswa gizi dan non-gizi di Universitas Muhammadiyah Surakarta memiliki gambaran kebiasaan sarapan dan status gizi yang tidak terlalu berbeda secara signifikan. Pengetahuan gizi yang dimiliki oleh mahasiswa gizi tidak secara langsung mengubah perilaku hidup sehat sehari-hari. Hal ini disebabkan karena ada banyak faktor yang mempengaruhi status gizi serta perilaku seseorang
\end{abstract}

Kata Kunci : sarapan, status gizi, mahasiswa gizi dan non gizi

\begin{abstract}
Nutrition students who get lectures on nutrition and health sciences are considered to have more knowledge than nonnutritional students. Nutrition knowledge of nutrition students would establish healthy life behavior such as healthy and regular breakfast habits that lead to optimal nutritional status. This study aim to describe breakfast habits and nutritional status of nutrition and non-nutrition students. This research method was an observational research with cross sectional design. The sample was chosen by purposive sampling, which were 39 nutrition students and 39 non-nutritional students. The data of type and frequency of breakfast were obtained with food record method for 7 consecutive days and nutritional status data (BMI / age) were taken with measurement of body weight and height. The results show that nutrition students (91.2\%) and non-nutrition students (79.4\%) were mostly having breakfast $<15 \%$ of RDI, had irregular frequency of breakfast (79.4\% for nutrition students and $100 \%$ for non-nutritional students) , as well as had good nutritional status $(70.6 \%$ for nutrition students and $61.8 \%$ for nonnutritional students). There was no significant differences of breakfast habits and nutritional status between nutrition and nonnutrition students at Universitas Muhammadiyah Surakarta. Nutrition knowledge of nutrition students does not directly change the daily healthy behaviors because there are many factors that affect nutritional status and behaviour.
\end{abstract}

Keywords: breakfast, nutrition status, nutrition and non-nutrition students 


\section{PENDAHULUAN}

Mahasiswa yang mengambil jurusan gizi dianggap memiliki pengetahuan tentang gizi dan kesehatan yang lebih dibandingkan dengan mahasiswa non-gizi. Selama perkuliahan, mahasiswa gizi mendapatkan materi-materi berdasarkan kurikulum yang berupa gizi klin$i k$, gizi masyarakat, gizi institusi, maupun gizi pangan serta bagaimana pengaruhnya terhadap kesehatan. Hal ini berbeda dengan mahasiswa non-gizi yang biasanya mendapatkan materi mengenai gizi dan kesehatan secara mandiri berdasarkan informasi yang mereka peroleh dari sekitar.

Kurikulum yang ada pada pendidikan gizi tidak hanya memberikan pengetahuan kepada mahasiswa tetapi juga diharapkan menjadi sarana untuk pembentukan sikap dan perilaku hidup sehat. Mahasiswa gizi memiliki peran dan tanggung jawab untuk menjalankan perilaku dan pola hidup sehat. Kehidupan mereka seharihari akan menjadi contoh bagi lingkungan sekitar untuk terciptanya kesehatan masyarakat yang berkesinambungan $^{1}$.

Menurut teori "Interactional Model of Client Health Behaviour", , pola atau perilaku hidup sehat pada setiap individu dipengaruhi oleh beberapa faktor, yaitu motivasi intrinsik, penilaian kognitif, dan respon afektif. Ketiga faktor ini saling berkaitan dan membentuk perilaku seseorang. Perilaku hidup sehat seseorang akan dipengaruhi oleh pilihan, motivasi, dan keinginan dari dalam diri sendiri. Selain itu, kemampuan kognitif dan faktor emosi juga dapat mempengaruhi seseorang dalam memilih untuk berperilaku hidup sehat.

Perilaku seseorang untuk hidup sehat akan bertahan lama apabila didasari oleh pengetahuan. Seseorang yang memiliki pengetahuan yang baik dalam bidang gizi akan lebih memahami tentang perilaku makan yang baik, seperti memilih jenis makanan yang sehat, makan dengan frekuensi yang teratur, dan menghindari makanan yang memberikan efek negatif bagi tubuh ${ }^{3}$. Selain itu, dengan memiliki pengetahuan yang baik maka seseorang akan cenderung untuk memilih aneka ragam makanan dan lebih selektif untuk memilih makanan yang sehat ${ }^{4}$.

Salah satu contoh perilaku hidup sehat dalam menjalankan pola gizi seimbang adalah membiasakan diri sarapan secara teratur. Menurut penelitian, mahasiswa yang memiliki kebiasaan sarapan teratur hanya sebanyak $44,8 \%{ }^{5}$. Kebiasaan sarapan yang tidak teratur pada sebagian mahasiswa disebabkan karena mahasiswa merasa tidak lapar, terlambat bangun, kurangnya waktu untuk sarapan, dan tidak tersedianya sarapan ${ }^{5}$. Terdapat beberapa faktor internal dan eksternal yang dapat mempengaruhi kebiasaan sarapan seseorang, Faktor internal yang mempengaruhi kebiasaan sarapan antara lain adalah usia, jenis kelamin, tempat tinggal, uang saku, dan ketersediaan pangan. Faktor eksternal yang berpengaruh antara lain adalah pola asuh, pendapatan dan pekerjaan orang tua, serta pengaruh dari teman sebaya ${ }^{6}$.

Mahasiswa gizi yang dianggap memiliki pengetahuan mengenai pentingnya sarapan bagi kesehatan dianggap akan memiliki kebiasan sarapan yang baik dan berkualitas. Akan tetapi, terdapat juga beberapa siswa yang sengaja melewatkan sarapan dengan alasan karena ingin menjaga berat badan yang ideal ${ }^{7}$. Hal ini merupakan anggapan yang salah di kalangan mahasiswa, sebab melewatkan sarapan akan berpengaruh terhadap status gizi seseorang. Kebiasaan sarapan yang baik berperan penting dalam pemenuhan kebutuhan gizi dan sumber tenaga di pagi hari. Seseorang yang melewatkan sarapan akan berakibat pada meningkatnya konsumsi pada waktu makan berikutnya. Hal ini dapat menyebabkan penimbunan lemak sehingga seseorang akan beresiko untuk mengalami status gizi lebih ${ }^{8}$.

Peneltian ini bertujuan untuk melihat gambaran kebiasaan sarapan dan status gizi pada mahasiswa gizi dan non-gizi di Universitas Muhammadiyah Surakarta. Mahasiswa gizi yang dianggap memiliki pengetahuan yang lebih baik mengenai gizi dan kesehatan diharapkan dapat memiliki perilaku kebiasaan sarapan yang baik untuk terwujudnya status gizi yang optimal.

\section{METODE}


Penelitian ini merupakan penelitian observasional dengan desain cross sectional. Penelitian dilakukan di Program Studi Ilmu Gizi, Akuntansi, dan Hukum Universitas Muhammadiyah Surakarta pada bulan September-Oktober 2017. Jumlah sampel dihitung dengan menggunakan rumus besar sampel uji hipotesis 2 proporsi dan diperoleh jumlah sampel untuk kelompok mahasiswa gizi dan non-gizi masing-masing 39 mahasiswa.

Sampel dipilih dengan cara purposive sampling berdasarkan kriteria inklusi: 1) Mahasiswa aktif angkatan 2014 dan 2015 berumur 19-23 tahun 2) Mahasiswa yang tinggal di kost 3) Mahasiswa tidak memiliki penyakit bawaan kronis 4) Mahasiswa yang dapat diukur antropometri. Kriteria eksklusi dari penelitian ini adalah: 1) Mahasiswa yang sedang melakukan diet 2) Mahasiswa yang rutin melakukan puasa sunnah.

Data kebiasaan sarapan responden diambil dengan menggunakan formulir food record selama 7 hari berturut-turut dan juga menggunakan kuesioner kebiasaan sarapan. Data yang diperoleh dari metode food record selanjutnya dianalisis dengan menggunakan $\mathrm{Nu}$ trisurvey untuk mendapatkan data jenis dan frekuensi sarapan. Responden dikatakan mengonsumsi jenis sarapan snack apabila kontribusi energi dari sarapan $<15 \%$ dari Angka Kecukupan Gizi (AKG) dan dikatakan mengonsumsi jenis sarapan meal apabila kontribusi energi dari sarapan $\geq 15 \%$ AKG. Frekuensi sarapan dikatakan sering apabila responden memiliki kebiasaan sarapan $\geq$ $4 \mathrm{x}$ seminggu dan dikatakan jarang sarapan apabila $<4 \mathrm{x}$ seminggu.

Status gizi mahasiswa diukur dengan metode antropometri. Berat badan diukur dengan timbangan injak dan tinggi badan diukur dengan mikrotoa. Status gizi mahasiswa dikategorikan berdasarkan Indeks Masa Tubuh (IMT). Mahasiswa dikatakan berstatus gizi baik apabila memiliki IMT 18,5 -25, status gizi kurang apabila IMT $<18,5$, dan status gizi lebih apabila IMT $>25$.
Berdasarkan tabel 1 (Lampiran), karakteristik responden pada penelitian ini diantaranya adalah dilihat dari usia, jenis kelamin, angkatan, besar uang saku, dan besar pengeluaran pangan. Berdasarkan hasil penelitian diketahui bahwa mayoritas usia responden baik pada mahasiswa gizi dan non-gizi adalah 20 tahun (44,1\% mahasiswa gizi dan 29,4\% mahasiswa non gizi) yang tersebar merata untuk angkatan 2014 dan 2015. Dilihat dari jenis kelaminnya, persentase responden laki-laki dan perempuan untuk mahasiswa non-gizi adalah sama (50\%) sedangkan pada mahasiswa gizi, responden lebih banyak berjenis kelamin perempuan $(67,6 \%)$. Dilihat dari besaran uang saku, mayoritas mahasiswa memiliki uang saku sama dengan atau di atas $\mathrm{Rp}$ 1.000.000. Pengeluaran untuk pangan bagi mahasiswa gizi mayoritas $(70,6 \%)$ adalah di atas rata-rata dan untuk mahasiswa non-gizi mayoritas $(52,9 \%)$ adalah di bawah rata-rata, dimana rata-rata pengeluaran pangan adalah $\mathrm{Rp}$ 600.000 .

Hasil penelitian ini menunjukkan bahwa mayoritas mahasiswa gizi dan non-gizi mengonsumsi makanan jenis snack, yaitu 91,2\% mahasiswa gizi mengonsumsi rata-rata $10,69 \%$ dari AKG dan $79,4 \%$ untuk mahasiswa non-gizi mengonsumsi $11,37 \%$ dari AKG (lihat tabel 2 dan tabel 3). Setelah dilakukan analisis dari hasil food record, diketahui bahwa jenis makanan yang banyak dikonsumsi oleh 2 kelompok responden ini juga memiliki kesamaan yaitu kebanyakan dari mahasiswa mengonsumsi roti, minuman, risoles, donat, coklat, dan biskuit.

Dilihat dari frekuensi kebiasaan sarapannya, mahasiswa baik dari gizi maupun non-gizi memiliki kebiasaan sarapan yang tidak teratur, yaitu $79,4 \%$ untuk mahasiswa gizi dan $100 \%$ untuk mahasiswa non-gizi (lihat tabel 4). Rata-rata frekuensi sarapan dalam 1 minggu untuk mahasiswa gizi adalah 1,74 kali dan untuk mahasiswa non-gizi adalah 0,73 kali (lihat tabel 5). Hasil tersebut menunjukkan bahwa mahasiswa gizi memiliki frekuensi sarapan yang lebih teratur dibandingkan dengan mahasiswa non-gizi akan tetapi perbedaannya tidak terlalu signifikan.

\section{HASIL}


Berdasarkan hasil penelitian diketahui bahwa mayoritas status gizi pada mahasiswa gizi dan non-gizi adalah status gizi baik yaitu $70,6 \%$ dengan rata-rata IMT 23,05 untuk mahasiswa gizi dan 61,8\% dengan rata-rata IMT 22,09 untuk mahasiswa non-gizi (lihat tabel 6 dan table 7). Hal ini sejalan dengan penelitian Bening dan Mayasari (2014) yang menyatakan bahwa tidak ada perbedaan status gizi antara mahasiswa gizi dan non-gizi. Tidak adanya perbedaan status gizi antara mahasiswa gizi dan non-gizi disebabkan karena terdapat banyak faktor yang dapat mempengaruhi status gizi seseorang.

\section{PEMBAHASAN}

Berbagai karakteristik responden dapat mempengaruhi kebiasaan sarapan maupun status gizinya. Penelitian menunjukkan bahwa semakin dewasa usia maka prevalensi sarapan teraturnya juga semakin tinggi dibandingkan dengan usia remaja ${ }^{9}$. Selain itu, semakin tinggi tingkat pendidikan (angkatan) seseorang maka tingkat pengetahuan gizinya juga akan semakin baik $^{3}$. Jenis kelamin juga mempengaruhi kebutuhan gizi sesorang dikarenakan massa otot laki-laki yang lebih besar dibandingkan perempuan ${ }^{10}$.

Berdasarkan penelitian, tingkat konsumsi seseorang juga tergantung dari besarnya uang saku dan juga pengeluaran pangan. Hal ini menunjukkan bahwa tingkat pendapatan dan pengeluaran pangan merupakan faktor tidak langsung yang mempengaruhi status gizi sesorang. Semakin besar uang saku dengan jumlah pengeluaran untuk pangan yang lebih dari rata-rata, maka akan semakin besar pula kesempatan yang dimiliki untuk membeli pangan yang berkualitas dan cukup sehingga status gizi akan lebih baik ${ }^{10}$.

Sarapan didefinisikan sebagai makanan pertama yang dikonsumsi dalam kurun waktu 2-3 jam setelah seseorang bangun tidur ${ }^{11}$. Sarapan dapat berupa makanan maupun minuman dari minimal 1 kelompok pangan, dan dapat dikonsumsi pada berbagai lokasi. Sarapan merupakan makanan yang utama karena sangat substansial sebagai pemenuhan energi seseorang ${ }^{12}$.
Sarapan yang berkualitas dapat dilihat dari beberapa faktor, salah satunya adalah total kontribusi energi dari sarapan. Sarapan dapat dikategorikan ke dalam 2 kelompok, yaitu sarapan jenis snack dan sarapan jenis meal. Sarapan dikategorikan sebagai snack apabila kontribusi energi dari sarapan kurang dari $15-30 \%$ dari total energi sehari dan sarapan dikatakan sebagai meal apabila memenuhi $15-30 \%$ dari total energi sehari ${ }^{13}$.

Kebiasaan mahasiswa gizi dan non-gizi dalam mengonsumsi sarapan dalam kategori snack disebabkan karena beberapa faktor, seperti: jadwal kuliah di pagi hari, tidak memiliki cukup waktu untuk sarapan, dan tidak ada keinginan untuk sarapan di pagi hari. Berbagai alasan tersebut menyebabkan mahasiswa memilih untuk membeli jajan di kantin. Pilihan makanan untuk sarapan mereka adalah makanan dalam bentuk snack dengan kandungan utama karbohidrat tanpa memperhitungkan berapa kontribusi energi yang diperoleh.

Jenis zat gizi yang terkandung dalam sarapan akan memberikan pengaruh terhadap performa mahasiswa. Konsumsi makanan yang mengandung tinggi karbohidrat dan rendah lemak seperti yang dikonsumsi oleh responden memiliki efek mengurangi kelelahan jika dibandingkan dengan kandungan sarapan dengan karbohidrat sedang. Akan tetapi, jumlah kontibusi energi dari sarapan yang masih termasuk dalam kategori rendah pada mayoritas responden juga memiliki dampak terhadap produktivitas mahasiswa. Menurut beberapa penelitian, mengonsumsi jenis sarapan dengan kandungan energi yang tinggi akan membantu siswa untuk meningkatkan kreatifitas, meningkatkan ketahanan fisik, dan berefek positif pada memori jangka pendek ${ }^{14-16}$. Sarapan yang berkualitas sebaiknya mengandung zat gizi campuran dari sumber karbohidrat, protein, dan lemak yang baik ${ }^{11}$.

Berdasarkan hasil penelitian, dapat dilihat bahwa jumlah kontribusi energi dari sarapan baik pada mahasiswa gizi dan non-gizi masih dalam kategori kurang. Hal ini menunjukkan bahwa walaupun mahasiswa gizi memiliki pemahanan pengetahuan tentang sarapan, akan tetapi hal tersebut tidak diikuti oleh implementasinya 
dalam kehidupan sehari-hari. Perbedaan sikap, persepsi, dan adanya hambatan terutama dalam hal manajemen waktu menjadi alasan utama bagi mahasiswa gizi dan non-gizi dalam memilih jenis sarapan ${ }^{11}$.

Kebiasaan sarapan mahasiswa dapat dilihat dari jumlah frekuensi sarapan dalam 1 minggu. Seseorang dikatakan teratur melakukan sarapan apabila melakukan sarapan lebih dari atau sama dengan 4 kali seminggu dan dikatakan tidak teratur apabila melakukan sarapan kurang dari 4 kali seminggu ${ }^{17}$. Pengetahuan yang dimiliki mahasiswa gizi mengenai manfaat sarapan teratur seharusnya dapat menjadi dasar dalam penerapan kebiasaan sarapan dalam kehidupan sehari-hari. Akan tetapi, pada kenyataannya banyak mahasiswa gizi yang masih belum menerapkan kebiasaan makan secara teratur. Hal ini disebabkan karena banyak faktor yang mempengaruhi seseorang dalam berperilaku sehari-hari, diantaranya adalah motivasi dalam diri sendiri untuk berperilaku sehat, faktor emosi, serta adanya pilihanpilihan $^{2}$. Selain itu, pembentukan sikap dan perilaku berdasarkan pengetahuan yang dimiliki juga memerlukan waktu yang lama.

Kebiasaan mahasiswa yang sarapan tidak teratur akan menimbulkan berbagai permasalahan, diantaranya adalah mempengaruhi kemampuan mahasiswa dalam memecahkan masalah, mempengaruhi memori jangka pendek, dan kemampuan penalaran menurunkan konsentrasi, serta menurunkan produktivitas kerja ${ }^{18}$. Selain itu, berdasarkan hasil wawancara kepada mahasiswa yang melewatkan sarapan diketahui bahwa sebagian responden mengalami lapar, lemas, pusing, mengantuk, namun ada juga yang tidak menimbulkan dampak apapun bagi mahasiswa.

Berdasarkan hasil wawancara kepada responden pada saat pengambilan data penelitian, diketahui bahwa lebih banyak mahasiswa yang mengonsumsi sarapan pada waktu hari libur dibandingkan dengan hari kuliah. Hal ini disebabkan karena sebagian mahasiswa biasanya kembali ke daerah asalnya saat hari libur. Faktor dari keluarga sangat berpengaruh secara signifikan terhadap kebiasaan sarapan mahasiswa ${ }^{9}$, karena pada saat maha- siswa kembali ke rumah maka akan tersedia makanan sehingga mahasiswa lebih termotivasi untuk sarapan ${ }^{11}$. Untuk mahasiswa yang tetap tinggal di kost, biasanya mereka akan memundurkan jam sarapan. Hal ini sesuai dengan penelitian Ozdogan (2010) yang menyatakan bahwa $26,9 \%$ mahasiswa sarapan di hari libur dan hanya $24,1 \%$ mahasiswa yang sarapan di hari kuliah ${ }^{5}$.

Status gizi pada kategori usia dewasa dapat dibedakan menjadi 3 macam, yaitu status gizi kurang (IMT <18,5), status gizi baik (IMT 18,5-25), dan status gizi lebih $(\text { IMT }>25)^{19}$. Status gizi menjadi perhatian yang sangat penting karena kekurangan maupun kelebihan berat badan dapat mempengaruhi produktivitas maupun menimbulkan resiko-resiko terjadinya penyakit ${ }^{10}$. Terdapat banyak faktor yang mempengaruhi status gizi seseorang. Faktor tersebut diantaranya adalah faktor internal yang meliputi usia, jenis kelamin, tempat tinggal, uang saku, kesediaan pangan, pengetahuan. Selain faktor internal, terdapat juga faktor eksternal yang mempengaruhi status gizi seseorang diantaranya adalah pola asuh, aktifitas fisik, pekerjaan orang tua, dan pengaruh teman sebaya ${ }^{6}$.

Berdasarkan penelitian Berkey, et al (2003), kebiasaan sarapan seseorang dapat mempengaruhi status gizinya. Seseorang dengan status gizi normal yang memiliki kebiasaan melewatkan sarapan akan memiliki kecenderungan mengalami peningkatan berat badan. Hal ini terjadi karena seseorang yang melewatkan sarapan akan cenderung memiliki asupan lemak yang berlebih dan asupan protein, energi, mineral, dan vitamin yang rendah $^{20}$.

Sarapan dapat mempengaruhi status gizi seseorang melalui beberapa mekanisme. Kebiasaan sarapan merupakan bagian dari pola makan yang seimbang, mampu meningkatkan komposisi diet sehari-hari, mempengaruhi jalur metabolisme, serta memberikan efek pada pengaturan nafsu makan ${ }^{21}$. Sarapan secara teratur yang mengandung tinggi serat dan karbohidrat memberikan efek rasa kenyang sehingga berhubungan dengan penurunan berat badan ${ }^{21}$. Selain itu, serat yang tinggi pada sarapan juga akan mempengaruhi respon 
insulin dan prostaglandin, memperbaiki sensitivitas insulin, mengurangi resiko hipoglikemi, serta memberikan efek rasa kenyang yang lama. Efek rasa kenyang yang timbul setelah mengonsumsi sarapan akan menyebabkan asupan energi menjadi rendah dan menyebabkan sesorang mengalami penurunan berat badan ${ }^{21}$.

\section{KESIMPULAN}

Mahasiswa gizi dan non-gizi di Universitas Muhammadiyah Surakarta memiliki gambaran kebiasaan sarapan dan status gizi yang tidak terlalu berbeda secara signifikan. Mayoritas dari mahasiswa gizi dan non-gizi mengonsumsi jenis sarapan snack $(<15 \% \mathrm{AKG})$ dengan frekuensi tidak teratur ( $<4 \mathrm{x}$ seminggu). Status gizi mahasiswa gizi dan non-gizi mayoritas adalah status gizi baik. Kebiasaan sarapan dan status gizi yang tidak berbeda secara signifikan antara mahasiswa gizi dan nongizi menunjukkan bahwa pengetahuan gizi yang diperoleh mahaiswa gizi di bangku kuliah tidak secara langsung mengubah perilaku hidup sehat sehari-hari.

Berdasarkan hasil penelitian ini dapat disarankan kepada pihak universitas untuk menjadi fasilitator untuk meningkatkan kebiasaan sarapan sehat mahasiswa. Selain itu, untuk penelitian selanjutnya dapat dikembangkan penelitian mengenai faktor-faktor lain yang dapat meningkatkan perilaku hidup sehat di kalangan mahasiswa.

\section{DAFTAR PUSTAKA}

1. Shriver CB, Scott-stiles A. Health Habits of Nursing versus Non- nursing Students : A Longitudinal Study. 1995.

2. science CC-A in nursing, 1982 An interaction model of client health behavior: theoretical prescription for nursing. journals.lww.com. http:// journals.lww.com/advancesinnursingscience/ Citation/1982/10000/

An_interaction_model_of_client_health_behavi or_-7.aspx. Accessed December $\overline{1} 3,201 \overline{7}$.

3. Apelabi MPP;, Nugroho A; Handini K. Perbedaan Pengetahuan Gizi dan Status Gizi Mahasiswa Tingkat 1 Sampai Tingkat Akhir pada Mahasiswa Program Studi S1 Ilmu Gizi Universitas Respati Yogyakarta. 2012.

4. Notoatmodjo S. Pendidikan Dan Perilaku
Kesehatan. Jakarta: Rineka Cipta; 2003.

5. Ozdogan Y, ... AO-PJ of, 2010 . The breakfast habits of female university students. researchgate.net. https:/www.researchgate.net/ profile/Yahya_Ozdogan/

publica-

tion/49965875_The_Breakfast_Habits_of_Fema le_University_Students/

links/548acec00cf2d1800d7afebf.pdf. Accessed December 13, 2017.

6. Saufika A, Retnaningsih R, Alfiasari A. Gaya Hidup dan Kebiasaan Makan Mahasiswa. J Ilmu Kel dan Konsum. 2012;5(2):157-165. doi:10.24156/jikk.2012.5.2.157.

7. Kesehatan CS-J, 2013. Globalisasi dan Pola Makan Mahasiswa, Studi Kasus di Jakarta. kalbemed.com. http://www.kalbemed.com/ portals/6/07 205Globalisasi dan Pola Makan Mahasiswa-Studi Kasus di Jakarta.pdf. Accessed December 13, 2017.

8. Kant AK, Andon MB, Angelopoulos TJ, Rippe JM. Association of breakfast energy density with diet quality and body mass index in American adults: National Health and Nutrition Examination Surveys, 1999-2004. Am J Clin Nutr. 2008;88(5):1396-1404. doi:10.3945/ AJCN.2008.26171.

9. Keski-Rahkonen A, Kaprio J, 2003. Breakfast skipping and health-compromising behaviors in adolescents and adults. nature.com. https:// www.nature.com/ejcn/journal/v57/n 7/

abs/1601618a.html. Accessed December 13, 2017.

10. Hardinsyah; Supariasa IDN. Ilmu Gizi Teori Dan Aplikasinya. Jakarta: EGC; 2016.

11. Neil CEO, Byrd-bredbenner C, Hayes D, Jana L, Klinger SE, Stephenson-martin S. and Criteria for a Quality Breakfast. J Acad Nutr Diet. 2014;114(12):S8-S26. doi:10.1016/ j.jand.2014.08.022.

12. Mahoney CR, Taylor HA, Kanarek RB, Samuel P. Effect of breakfast composition on cognitive processes in elementary school children. 2005;85:635-645. doi:10.1016/ j.physbeh.2005.06.023.

13. Khomsan A. Kebiasaan sarapan pada mahasiswa Tpb Ipb dengan status gizi normal dan Obes. 2014. http://repository.ipb.ac.id/ handle/123456789/72147. Accessed December 13, 2017.

14. Busch C, Taylor H, Kanarek R, behavior PH$P \&, 2002$. The effects of a confectionery snack on attention in young boys. Elsevier. http:// www.sciencedirect.com/science/article/pii/ S003193840200882X. Accessed December 13, 2017. 
15. Wyon DP, Abrahamsson L, Järtelius M, Fletcher RJ. An Experimental Study of the Effects of Energy Intake at Breakfast on the Test Performance of 10-Year-Old Children in School. Int J Food Sci Nutr. 1997;48(1):5-12. doi:10.3109/09637489709006958.

16. Michaud C, Musse N, Nicolas J, Health LM-J of A, 1991. Effects of breakfast-size on shortterm memory, concentration, mood and blood glucose. Elsevier. http:// www.sciencedirect.com/science/article/ pii/019700709190042K. Accessed December 13, 2017.

17. Yang R-J, Wang EK, Hsieh Y-S, Chen M-Y. Irregular breakfast eating and health status among adolescents in Taiwan. BMC Public Health. 2006;6(1):295. doi:10.1186/1471-24586-295.

18. Márquez A, Sutil N, YR-A, 2001. Influence of breakfast on cognitive functions of children from an urban area in Valencia, Venezuela. europepmc.org. $\mathrm{http} / /$ europepmc.org/abstract/ med/11515233. Accessed December 13, 2017.

19. WHO. World Health Statistics. Genewa; 2007.

20. Berkey CS, Rockett HRH, Gillman MW, Field AE, Colditz GA. Longitudinal study of skipping breakfast and weight change in adolescents. 2003:1258-1266. doi:10.1038/sj.ijo.0802402.

21. Timlin MT, Pereira MA. Breakfast Frequency and Quality in the Etiology of Adult Obesity and Chronic Diseases. Nutr Rev. 2008;65 (6):268-281. doi:10.1111/j.17534887.2007.tb00304.x. 


\section{LAMPIRAN}

Tabel 1 Karakteristik Responden

\begin{tabular}{|c|c|c|c|c|}
\hline & & Gizi & & on Gizi \\
\hline & Jumlah (n) & Persentase (\%) & Jumlah (n) & Persentase (\%) \\
\hline Umur Responden & & & & \\
\hline 19 & 6 & 17,6 & 5 & 14,7 \\
\hline 20 & 15 & 44,1 & 10 & 29,4 \\
\hline 21 & 11 & 32,4 & 11 & 32,4 \\
\hline 22 & 2 & 5,9 & 7 & 20,6 \\
\hline 23 & 0 & 0,0 & 1 & 2,9 \\
\hline Jenis Kelamin & & & & \\
\hline Perempuan & 23 & 67,6 & 17 & 50 \\
\hline Laki-laki & 11 & 32,4 & 17 & 50 \\
\hline Angkatan & & & & \\
\hline 2014 & 17 & 50 & 16 & 47,1 \\
\hline 2015 & 17 & 50 & 18 & 52,9 \\
\hline Besar Uang Saku & & & & \\
\hline$<\operatorname{Rp} 600.000$ & 2 & 5,9 & 4 & 11,8 \\
\hline Rp 600.000-Rp 999.000 & 10 & 29,4 & 13 & 38,2 \\
\hline$\geq \operatorname{Rp~} 1.000 .000$ & 22 & 64,7 & 17 & 50 \\
\hline Pengeluaran Pangan & & & & \\
\hline$\geq \operatorname{Rp} 600.000$ & 24 & 70,6 & 16 & 47,1 \\
\hline$<\operatorname{Rp} 600.000$ & 10 & 29,4 & 18 & 52,9 \\
\hline
\end{tabular}

Tabel 2 Jenis Sarapan Mahasiswa Gizi dan Non-Gizi

\begin{tabular}{lllll}
\hline Jenis Sarapan & \multicolumn{1}{c}{ Gizi } & \multicolumn{2}{c}{ Non-Gizi } \\
\hline & Jumlah (n) & Persentase (\%) & Jumlah (n) & Persentase (\%) \\
\hline Snack & 31 & 91,2 & 27 & 79,4 \\
Meal & 3 & 8,8 & 7 & 20,6 \\
Total & 34 & 100 & 34 & 100 \\
\hline
\end{tabular}

Tabel 3 Statistik Deskriptif Jenis Sarapan Mahasiswa Gizi dan Non-Gizi

\begin{tabular}{lll}
\hline Jenis Sarapan & & Mahasiswa \\
\hline & Gizi & Non-Gizi \\
\hline Minimal & 2,05 & 2,84 \\
Maksimal & 18,61 & 34,88 \\
Rata-rata & 10,69 & 11,37 \\
Standar Deviasi & 4,16 & 6,14 \\
\hline
\end{tabular}


Tabel 4 Frekuensi Sarapan Mahasiswa Gizi dan Non-Gizi

\begin{tabular}{lllll}
\hline Frekuensi Sarapan & & Gizi & \multicolumn{2}{c}{ Non-Gizi } \\
\hline & Jumlah (n) & Persentase (\%) & Jumlah (n) & Persentase (\%) \\
\hline Teratur (<4x/minggu) & 7 & 20,6 & 0 & 0 \\
Tidak teratur ( $\geq 4 \mathrm{x} /$ minggu) & 27 & 79,4 & 34 & 100 \\
Total & 34 & 100 & 34 & 100 \\
\hline
\end{tabular}

Tabel 5 Statistik Deskriptif Frekuensi Sarapan Mahasiswa Gizi dan Non-Gizi

\begin{tabular}{lcc}
\hline Frekuensi Sarapan & & Mahasiwa \\
\hline Minimal & Gizi & Non-Gizi \\
Maksimal & 0,00 & 0,00 \\
Rata-rata & 5,00 & 3,00 \\
Standar Deviasi & 1,26 & 0,73 \\
& 1,74 & 0,89 \\
\hline
\end{tabular}

Tabel 6 Status Gizi Mahasiwa Gizi dan Non-Gizi

\begin{tabular}{llllc}
\hline Status Gizi & & Gizi & \multicolumn{2}{c}{ Non-Gizi } \\
\hline & Jumlah (n) & Persentase (\%) & Jumlah (n) & Persentase (\%) \\
\hline Gizi Kurang & 2 & 5,9 & 8 & 23,5 \\
Gizi Baik & 24 & 70,6 & 21 & 61,8 \\
Gizi Lebih & 8 & 23,5 & 5 & 14,7 \\
Total & 34 & 100 & 34 & 100 \\
\hline
\end{tabular}

Tabel 7 Statistik Deskriptif Status Gizi Mahasiswa Gizi dan Non-Gizi

\begin{tabular}{lcc}
\hline Status Gizi & & Mahasiwa \\
\hline Minimal & Gizi & Non-Gizi \\
Maksimal & 16,99 & 17,00 \\
Rata-rata & 34,31 & 37,60 \\
Standar Deviasi & 23,05 & 22,09 \\
& 4,64 & 5,46 \\
\hline
\end{tabular}

